\title{
Can Surgical Technique Affect the Success of Endoscopic Treatment in Children with Vesicoureteral Reflux and Overactive Bladder Syndrome?
}

\section{Vezikoüreteral Reflü ve Ašıı Aktif Mesane Birlikteliğinde Farklı Endoskopik Cerrahi Teknikler Tedavi Başarısını Etkiler mi?}

\author{
Ahmet Şahan, Cem Akbal, Asgar Garayev, Çağrı Akın Şekerci, Muhammed Sulukaya, \\ Yılören Tanıdır, Illker Tinay, Tufan Tarcan, Ferruh Şimşek
}

Marmara University Faculty of Medicine, Department of Urology, Istanbul, Turkey

What's known on the subject? and What does the study add?

The surgical correction of vesicouretral reflux in children with concomitant overactive bladder is a challenging issue in pediatric urology practice. While no significant difference exists between the success rates of the STING and Double-HIT treatment methods, the presence of high-grade reflux is a parameter that can be used to predict the success of the treatment in patient with concomitant overactive bladder.

\begin{abstract}
Objective

"Traditional subureteral transurethral injection" (STING) and "Double hydrodistention-implantation" (Double-HIT) injection techniques for vesicoureteral reflux (VUR) treatment are a less invasive, yet very effective options. The influence of injection techniques in treatment success is not adequately searched in children with overactive bladder syndrome (OAB). The objective of this study to compare the short-term success rates of STING and Double-HIT techniques in children with OAB-VUR complex.
\end{abstract}

\section{Materials and Methods}

Children who underwent endoscopic injection for VUR between 2010 and 2013 were retrospectively evaluated. Patients were grouped into two groups according to the surgical techniques (STING or DoubleHIT). Success of the treatment was defined with a negative voiding cystourethrogram at the $6^{\text {th }}$ postoperative week. Patients were evaluated according to sex, age, pre- and postoperative reflux grades, laterality, type and volume of bulking agent and presence of $O A B$.

\section{Results}

Both groups were similar in terms of sex, age, lower urinary tract dysfunction, reflux grade and success rates. Surgical technique, score of pediatric lower urinary tract symptom questionnaire, age, sex, laterality of reflux and type of the bulking agent found to have no effect on the overall success rates $(p>0.05)$. Presence of $O A B$ and/or a high grade reflux were identified as statistically significant predictive factors that could affect the treatment results.

\section{ÖZET}

Amaç

Vezikoüreteral reflü (VUR) tedavisi için kullanılan cerrahi yöntemlerden subüreteral transüretral enjeksiyon (STING) ve çift hidrodistansiyonimplantasyon (Double-HIT) enjeksiyon teknikleri daha az invazif ve etkili tedavi seçenekleridir. Aşırı aktif mesane (AAM) ve VUR birlikteliği olan çocukların tedavilerinde enjeksiyon tekniklerinin etkisi henüz yeterince araştırılmamıștır. Bu çalışmanın amacı AAM-VUR birlikteliği olan çocukların tedavisinde STING ve Double-HIT tekniklerinin kısa süreli başarı oranlarının karşılaştııılmasıdır.

\section{Gereç ve Yöntem}

Kliniğimizde 2010-2013 yılları arasında VUR tedavisi için endoskopik enjeksiyon yapılan çocuklar retrospektif olarak değerlendirildi. Çocuklar kullanılan cerrahi tekniğe göre (STING veya Double-HIT ) iki gruba ayrıldı. Tedavinin başarısı postoperatif 6 . haftadaki işeme sistoüretrogramında (ISUG) reflünün tamamen kaybolması olarak tanımlandı. Hastalar cinsiyet, yaş, preoperatif ve postoperatif reflü derecesi, tek-çift taraf, enjeksiyon materyali tipi ile hacmine ve AAM varlığına göre değerlendirildi.

Bulgular

Her iki grup cinsiyet, yaş, alt üriner sistem disfonksiyonu ve reflü derecesi varlığı açısından benzerdi. Kullanılan cerrahi tekniğin, pediatrik alt üriner sistem semptomları anket skorunun, yaşın, cinsiyetin, reflü tarafının ve enjeksiyon materyalinin türünün; genel başarı oranları $(p>0,05)$ üzerine anlamlı bir etkisi yoktu. Yüksek dereceli VUR tedavisinde AAM'nin varlığı tedavi başarısını öngörmede istatistiksel olarak anlamlı bir faktör olarak bulundu.

\section{Correspondence}

Cem Akbal MD, Marmara University Faculty of Medicine, Department of Urology, İstanbul, Turkey

Phone: +90 5323410779 E-mail: cakbal@gmail.com Received: 03.06.2015 Accepted: 11.06.2015 


\section{ABSTRACT}

\section{Conclusion}

The short-term surgical success of the double-HIT and STING techniques showed no difference in children with $\mathrm{OAB}$. The presence of a high grade reflux and/or $O A B$ seemed to be the main factors for overall success in endoscopic VUR surgery.

\section{Key Words}

Pediatrics, vesicoureteral reflux, overactive bladder, endoscopic surgery, surgery, therapy

\section{Introduction}

Endoscopic injection treatment for vesicoureteral reflux (VUR) is a less invasive, yet very effective surgical option. Following the commercial release of dextranomer/hyaluronic acid copolymer (Dx/HA) material, it has became increasingly common with success rates of $83.0 \%$ (95\% $\mathrm{Cl}, 69.1-91.4 \%$ ) following the first injection (1). Not long ago, Kirsch et al. (2) offered an alternative technique for the traditional subureteral transurethral injection (STING) method and with their new technique, they report higher cure rates in endoscopic vesicoureteral reflux (VUR) surgery which evolved from 79\% up to 92\%. This new form of STING application suggests intraureteral injection of Dx/HA and is thought to provide a better coaptation (2). This technique of Kirsh, hydrodistention implantation technique (HIT), was further modified into another one with the injection of Dx/HA both into the ureter and into the ureteral orifice (double-HIT) by Molitierno et al. (3) and Kalisvaart et al. (4). In their original work, they reported better results, with a success rate of 92-93\% for double-HIT technique. This two-step technique provides a sufficient bulge and a coaptation of the detrusor tunnel and helps ureteral orifice to have a better coaptation, respectively (5). In both injection techniques, an optimal bolus and slit-like ureteral orifice appearance has been reported (6). Migration of the bulking agent, insufficient injection, inappropriate localization for injection, extrusion of the implant, and multiple mucosal ruptures are the proposed failure reasons for STING (5). Predictive factors for treatment success include pre/post-operative ureteral orifice morphology, grade of preoperative reflux, appropriate injection volume and presence of lower urinary tract dysfunction (LUTD) $(5,7,8)$. More recent studies report similar success rates for HIT, double-HIT and STING techniques in contrast to former literature, which suggests double-HIT method as being more effective $(3,4,9,10)$. According to 2010 AUA guidelines, the rate of reflux resolution at the 24th month after diagnosis is much lower for children with LUTD $(31 \%)$ than it is for children without it $(61 \%)(1)$. The rate of cure following endoscopic therapy is less in children with than it is for children without LUTD, but there is no difference in the case of open surgery $(1,11,12)$. The influence of injection techniques on treatment success is not adequately searched in children with overactive bladder $(O A B)$. The present study aims to assess results and success rates of both injection techniques in children with VUR and OAB complex.

\section{Materials and Methods}

\section{Patients and Diagnosis of Reflux}

Previously detected VUR patients, who underwent an endoscopic injection treatment between February 2010 and February 2013, were

\section{ÖZET}

Sonuç

Double-HIT veya STING tekniği kullanarak tedavi edilen AAM'li çocuklarda kısa süreli cerrahi başarı oranları önemli bir fark göstermemektedir. Yüksek dereceli VUR ve/veya AAM varlığı endoskopik VUR cerrahisi başarısını veya başarısızlığını belirleyen temel faktörler olarak görülmektedir.

\section{Anahtar Kelimeler}

Pediatri, vezikoüreteral reflü, aşırı aktif mesane, endoskopik cerrahi, tedavi, cerrahi

enrolled into the present study. Each child's age, gender, pediatric lower urinary tract symptom score (PLUTSS), two-day voiding dairy data, constipation history, genital and sacral examinations, uroflow/ EMG study, urinary ultrasonography, voiding cystouretrography (VCUG), and dimercaptosuccinicacid sintigraphy (DMSA) results were recorded. This study was approved by the Local Ethics Committee and conducted in accordance with the ethical principles described by the Declaration of Helsinki (ID: 09.2014.0121).

\section{Diagnosis and Treatment of $O A B$}

Patients who met the following three criteria were classified as suffering from $O A B$ and were selected as the study group: (1) sudden, imperative urinary urgency with or without urge incontinence; (2) need for holding maneuvers; (3) a minimum of seven small-volume urinations per day. Findings that supported the diagnosis of $O A B$ were normal or low bladder capacity and a post-void residual urine volume of $<20 \mathrm{~mL}$ (7). Each patient and his/her parents completed a originally developed and validated score (PLUTSS) for lower urinary tract symptoms at the initial evaluation phase and 6 months thereafter (13).

Each patient completed a 2-day bladder diary with entries as per International Children's Continence Society (ICCS) recommendations (7).

Patients with $O A B$ were treated with anticholinergics $(0.1-0.3 \mathrm{mg} / \mathrm{kg})$ and urotherapy for minimum 6 months. Finally, patients with persisting reflux were included in the study. Children having complex VUR, a history of previous reflux surgery, neurogenic bladder, duplicated ureter, ectopic ureter, or posterior urethral valve were excluded from the study. VUR diagnoses and grading was carried out according to the International Reflux Study Criteria (14). Recurrent febrile urinary tract infections despite appropriate antibiotic prophylaxis, presence of newly diagnosed renal scarring, persisting or worsening of VUR following $O A B$ treatment and family will were the main indications for endoscopic VUR surgery.

\section{Surgical Technique}

Operations were performed under general anesthesia with 0-5 degree lens through a $10.5 \mathrm{Fr}$ pediatric cystoscope. Any endoscopic treatment needs the placement of cystoscope at the ureteral orifice and placing the irrigation bag approximately 1 meter above the bladder on full flow for hydrodistention of the intramural ureter and a fine pressure stream.

STING procedure involves placement of the needle just in front of the ureteral orifice at a 6 o'clock position and introduction of the needle to the depth of 2-3 $\mathrm{mm}$ of bladder mucosa (6). The injection is 
continued until a satisfactory bulge and a good shut tight coaptation is gained at the ureteral orifice, like a volcano (6).

Double-HIT involves placement of the needle to the mid-ureteral tunnel and injection of bulking agent at the 6 o clock position after a prior injection of the implant under the intramural ureter; thus, preventing the risk of displacement of the implant and providing a better ureteral tunnel coaptation $(5,15)$. Dx/HA implant materials used for injections were either DEXELL VUR ${ }^{\circledR}$ (80-120 microns; Elit Medikal, Ankara-TURKEY) or DEFLUX ${ }^{\circledR}$ (80-250 micron; Oceana Therapeutics Ltd., Dublin-IRELAND). For evaluation of surgical success, an ultrasound and VCUG imaging were performed at $6^{\text {th }}$ postoperative week for Dexell and 3 months for Deflux. We monitored initially reflux-free patients for febrile urinary tract infection (UTI), VUR relapse and voiding dysfunction (VD) presence, laterality, need for control VCUG and time to relapse.

\section{Statistical Analysis}

Statistical analyses were performed with IBM SPSS Statistics for Windows, Version 20.0 (Armonk, NY: IBM Corp.) Chi-square and Fisher's exact tests were used where appropriate. The univariate analyses were done by using the chi-square, Fisher's exact, student's t-test, and the Mann-Whitney $U$ tests where appropriate. In multivariate analyses, logistic regression analyses were done to determine independent predictors. Tests were considered statistically significant when $p$ values were less than 0.05

\section{Results}

Of all patients, 82 children received a subureteric injection via STING technique and 31 received via double-HIT injection technique. Both groups were similar in terms of sex, age, PLUTSS, reflux laterality, preoperative reflux grade and success rates $(p>0.05)$ (Table 1). Demographic findings in each group are provided in Table 1.

Surgical technique was found to have no statistically significant effect on success/failure rates when compared in a subgroup analysis according to reflux grade, treated ureteral unit, treated patient number and presence of OAB (Table 2) ( $p>0.05$ ). In univariate analysis, treatment efficacy was found to be influenced by age, PLUTSS, accompanying OAB, and preoperative reflux grade (Table 3$)(p<0.05)$. On the other hand, sex, reflux laterality, type of bulking agent, and surgical technique had no influence on treatment success (Table 3) ( $p>0.05$ ).

Binary logistic regression analyses of surgical technique, presence of $O A B$, presence of a high reflux grade, PLUTSS and age revealed significant effect of accompanying $\mathrm{OAB}$ and high grade reflux on treatment success (Table 4).

During the long-term follow-up, 13 (15.8\%) of the 82 initially refluxfree patients developed febrile UTI and underwent VCUG. Seven (8\%) of them had recurrences. Three ipsilateral and 4 new contralateral VUR were documented. Lower urinary tract symptoms were reported in 4 of 13 patients. Two of them developed contralateral VUR and

Table 1. Descriptive statistics of the study groups are given

\begin{tabular}{|c|c|c|c|c|}
\hline & & Double HIT & STING & $p$ value \\
\hline \multirow[t]{2}{*}{ Sex } & Male & $1(6.7 \%)$ & $14(93.3 \%)$ & \multirow[t]{2}{*}{$0.06^{*}$} \\
\hline & Female & $30(30.6 \%)$ & $68(69.4 \%)$ & \\
\hline \multicolumn{2}{|l|}{ Age by years (Mean \pm SD) } & $7.8 \pm 2.6$ years & $7.3 \pm 3.3$ years & $0.42^{\infty}$ \\
\hline \multicolumn{2}{|l|}{ PLUTSS (Mean \pm SD) } & $9.6 \pm 8.2$ & $11.8 \pm 5.5$ & $0.14 \mu$ \\
\hline \multicolumn{2}{|l|}{ Dx/HA volume by $\mathrm{ml}$ (Mean \pm SD) } & $1.37 \pm 0.35 \mathrm{ml}$ & $1.25 \pm 0.54 \mathrm{ml}$ & $0.286 \beta$ \\
\hline \multirow[t]{2}{*}{ Laterality } & Unilateral & $23(74.2 \%)$ & $52(63.4 \%)$ & \multirow[t]{2}{*}{$0.375^{*}$} \\
\hline & Bilateral & $8(25.8 \%)$ & $30(36.6 \%)$ & \\
\hline \multirow[t]{2}{*}{ Age } & $<5$ years & $4(12.9 \%)$ & $17(20.7 \%)$ & \multirow[t]{2}{*}{$0.177^{*}$} \\
\hline & zyears & $27(87.0 \%)$ & $65(79.3 \%)$ & \\
\hline \multirow[t]{2}{*}{ LUTD } & $O A B$ & $13(41.9 \%)$ & $41(50 \%)$ & \multirow[t]{2}{*}{$0.444^{*}$} \\
\hline & Normal & $18(58.1 \%)$ & $41(50 \%)$ & \\
\hline \multirow[t]{2}{*}{ Dx/HA material } & DEFLUX ${ }^{\circledR}$ & $0(0 \%)$ & $76(100 \%)$ & \multirow[t]{2}{*}{0.001} \\
\hline & DEXELL ${ }^{\circledR}$ VUR & $62(41.3 \%)$ & $88(58.7 \%)$ & \\
\hline \multirow{4}{*}{ VUR grade } & 1 & $6(9.7 \%)$ & $9(5.5 \%)$ & \multirow[t]{4}{*}{$0.154^{*}$} \\
\hline & 2 & $21(33.9 \%)$ & $46(28.0 \%)$ & \\
\hline & 3 & $10(16.1 \%)$ & $35(21.3 \%)$ & \\
\hline & 4 & $2(3.2 \%)$ & $21(12.8 \%)$ & \\
\hline
\end{tabular}




\section{Table 2. Treatment results of subureteric injection techniques are compared}

\begin{tabular}{|l|l|l|l|l|l|}
\hline \multirow{3}{*}{$\begin{array}{l}\text { Treatment results } \\
\text { (According to reflux grade) }\end{array}$} & & Double HIT & STING & Total & $p$ value \\
\cline { 2 - 6 } & Grade 1 & $4 / 6(66.7 \%)$ & $9 / 9(100 \%)$ & $13 / 15(86.7 \%)$ & $0.143^{\infty}$ \\
\cline { 2 - 6 } & Grade 2 & $18 / 21(85.7 \%)$ & $39 / 46(84.8 \%)$ & $58 / 67(85.1 \%)$ & $0.921 \beta$ \\
\cline { 2 - 7 } & Grade 3 & $7 / 10(70 \%)$ & $27 / 35(77.1 \%)$ & $34 / 45(75.6 \%)$ & $0.687^{\infty}$ \\
\cline { 2 - 7 } & Grade 4 & $0 / 2(0 \%)$ & $11 / 21(52.4 \%)$ & $11 / 23(47.8 \%)$ & 0.478 \\
\hline Ureteral unit & & $29 / 39(74.4 \%)$ & $86 / 111(77.5 \%)$ & $117 / 150(76.6 \%)$ & $0.692 \beta$ \\
\hline Patient number & & $22 / 31(71.0 \%)$ & $61 / 82(74.4 \%)$ & $83 / 113(73.4 \%)$ & $0.713 \beta$ \\
\hline \multirow{2}{*}{ LUTD } & OAB & $10 / 17(58.8 \%)$ & $34 / 54(63.0 \%)$ & $44 / 71(61.9 \%)$ & $0.759 \beta$ \\
\cline { 2 - 6 } & Normal & $19 / 22(86.4 \%)$ & $52 / 57(91.2 \%)$ & $81 / 101(80.1 \%)$ & $0.679 \beta$ \\
\hline
\end{tabular}

$\infty$ (fisher's exact test), $\beta$ (Chi-square),

LUTD: Lower urinary tract dysfunction, STING: Traditional subureteral transurethral injection, Double HIT: Double hydrodistention-implantation,

LUTD: Lower urinary tract dysfunction, OAB: Overactive bladder

\section{Table 3. Treatment success is compared according to various variables with univariate analysis}

\begin{tabular}{|c|c|c|c|c|}
\hline & & Treatment success $(n=115)$ & Treatment failure $(n=35)$ & $p$ value \\
\hline \multirow[t]{2}{*}{ Sex } & Female & $97(77.0 \%)$ & $29(23.0 \%)$ & \multirow[t]{2}{*}{$0.833^{*}$} \\
\hline & Male & $18(75.0 \%)$ & $6(25.0 \%)$ & \\
\hline Age by years (Mean $\pm S D$ ) & Total & $7.6 \pm 3.3$ & $6.3 \pm 3.0$ & $0.03 \beta$ \\
\hline PLUTSS (Mean \pm SD) & & $10.5 \pm 6.3$ & $14.7 \pm-6.3$ & $0.01 \beta$ \\
\hline \multirow[t]{2}{*}{ Age } & $<5$ years & $20(62.5 \%)$ & $12(37.5 \%)$ & \multirow[t]{2}{*}{$0.033^{*}$} \\
\hline & $\geq$ years & $95(\% 80.5 \%)$ & $23(19.5 \%)$ & \\
\hline \multirow[t]{2}{*}{ OAB (Total 28) } & Yes & $44(62.0 \%)$ & $27(38.0 \%)$ & \multirow[t]{2}{*}{$0.001^{*}$} \\
\hline & No & 71 (89.9\%) & $8(10.1 \%)$ & \\
\hline \multirow{4}{*}{ Preoperative reflux grade } & Grade 1 & $13(86.7 \%)$ & $2(13.3 \%)$ & \multirow[t]{4}{*}{$0.003^{*}$} \\
\hline & Grade 2 & $57(85.1 \%)$ & $10(14.9 \%)$ & \\
\hline & Grade 3 & $34(75.6 \%)$ & $11(24.4 \%)$ & \\
\hline & Grade 4 & $11(47.8 \%)$ & $12(52.2 \%)$ & \\
\hline Dx/HA volume (Mean, min-max) & & $1.30(0.5-2.0)$ & $1.23(1.0-2.0)$ & $0.353^{\infty}$ \\
\hline \multirow[t]{2}{*}{ Laterality } & Unilateral & $27(87.1 \%)$ & $4(12.9 \%)$ & \multirow[t]{2}{*}{$0.233^{*}$} \\
\hline & Bilateral & $28(75.7 \%)$ & $9(24.3 \%)$ & \\
\hline \multirow[t]{2}{*}{ Bulking agent } & DEFLUX® & $39(76.5 \%)$ & $12(23.5 \%)$ & \multirow[t]{2}{*}{$0.967^{*}$} \\
\hline & DEXELL VUR ${ }^{\circledR}$ & 76 (76.8\%) & $23(23.2 \%)$ & \\
\hline \multirow{2}{*}{$\begin{array}{l}\text { Injection technique } \\
\text { (For all Dx/HA materials) }\end{array}$} & STING & $86(74.4 \%)$ & $25(25.6 \%)$ & \multirow[t]{2}{*}{$0.692^{*}$} \\
\hline & Double HIT & $29(77.5 \%)$ & $10(22.5 \%)$ & \\
\hline \multirow{2}{*}{\begin{tabular}{|l|} 
Injection technique \\
(For only DEXELL VUR
\end{tabular}} & STING & $47(78.3 \%)$ & $13(21.7 \%)$ & \multirow[t]{2}{*}{$0.647^{*}$} \\
\hline & Double HIT & 29 (74.4\%) & $10(25.6 \%)$ & \\
\hline
\end{tabular}


Table 4. Binary logistic regression analyses of variables that might have an effect on treatment success are provided with confidence interval

\begin{tabular}{|l|l|l|l|l|}
\hline & Sig. & Exp (B) & \multicolumn{2}{l|}{$95 \%$ C.I. for Exp (B) } \\
\cline { 3 - 5 } & & & Lower & Upper \\
\hline OAB vs. Normal function & .036 & 3.375 & 1.085 & 10.498 \\
\hline $\begin{array}{l}\text { Reflux } \\
\text { (Grade 1-2 vs. Grade 3-4) }\end{array}$ & .028 & 2.996 & 1.123 & 7.993 \\
\hline $\begin{array}{l}\text { Reflux } \\
\text { (Grade 1-2-3 vs. Grade 4) }\end{array}$ & .008 & 4.391 & 1.473 & 13.087 \\
\hline Double HIT vs. STING & .267 & 1.737 & 0.655 & 4.606 \\
\hline PLUTSS & .175 & .944 & 0.869 & 1.026 \\
\hline Age & .282 & 1.087 & 0.934 & 1.265 \\
\hline
\end{tabular}

OAB: Overactive Bladder, PLUTSS: Pediatric lower urinary tract symptom score, STING: Traditional subureteral transurethral injection, Double HIT: Double hydrodistention-implantation

one of them had ipsilateral VUR. Four of 7 patients with recurrence underwent subureteric injection via STING technique and the rest 3 received via double-HIT injection technique. The mean reflux recurrence time was 16 months.

\section{Discussion}

The present study retrospectively analyzed the effect of age, sex, the type and amount of injected agent, laterality, reflux grade, PLUTSS and presence of $O A B$ in endoscopic treatment of VUR. Finally, we found that being younger ( $<5$ years), having a low PLUTSS, having a reflux of low grade, and being without $O A B$ seemed to increase the success of endoscopic VUR treatment. According to regression logistic analyses, reflux grade and accompanying $O A B$ seemed to be the ultimate factors determining overall success of endoscopic surgery.

Similar to the present study, a meta-analysis covering 17.972 patients reported high success rates for VUR treatment via endoscopic treatment and open surgery as $83 \%$ and $98.1 \%$, respectively (1). Interestingly, our success rate for endoscopic treatment of VUR was slightly low (76.7\%) compared to the meta-analysis. Some authors think endoscopic treatment can even be spared for high-grade reflux. Altug et al. (15) reported a 54.8\% cure rate for grade 3-4-5 reflux after first injection treatment. However, most of the endoscopic treatments in grade 5 reflux patients were reported as failed, so the actual cure rates for grade 3-4 reflux appeared to be much higher as $66.1 \%$. We do not think that endoscopic treatment is the right treatment modality for a VUR with grade 5 , and our cure rates for grade 3-4 and grade 4 were $66.2 \%$ and $48.7 \%$, respectively.

Watters et al. (9) reported ureteral reflux resolution as 79.75\% and $80.84 \%$ for STING and HIT techniques, respectively $(p=0.86)$. On the other hand, Yucel et al. (8) reported successful reflux resolution in 124 ureters (84\%) with a single implantation, including 83 (86.5\%) with double-HIT and 41 (79\%) with HIT techniques ( $p=0.23)$. Similarly, we could not find any statistically significant difference between either techniques (74.4\% vs. 77.5\%). However, a debate about this topic still goes on since some of the recent studies, like the one performed by Routh et al.(16) reported double-HIT technique being more effective although this did not achieve statistical significance. Watters et al. (9) could not find any effect of injection technique, patients' sex, presence of $\mathrm{VD}$, and orifice morphology on success rate $(0 R=4.4, p=0.004)$, but they found two significant predictors of treatment success which were being younger than 6 years and using moderated amount of Dx/ $\mathrm{HA}$ volume $(\mathrm{OR}=2.7, \mathrm{p}=0.003)$ (9). We also have a similar experience with age. Since toilet training is generally expected to be gained at age 5, we preferred to analyze patients prior or after age 5; talking about our cohort patients younger than 5 years old seemed to have a higher failure rate (37.5\% vs. 19.5\%).

Several case studies have been published reporting various causes affecting surgical success rates like the injection method used, preoperative reflux grade, pre/post-operative ureter orifice morphology, amount of injected Dx/HA, and associated any lower urinary tract dysfunction $(8,17,18)$. Lavelle et al. (18) reported postoperative ureter orifice morphology to be the main factor of success. Unlike us, they did not perform urodynamic studies and did not use any questionnaire in the evaluation of VD, and did not find VD and reflux grade to be the predictive factors. Mendez et al. (16) investigated the effect of laterality of reflux and presence of either VD or nephropathy; and found only reflux grade to be a significant predictor of treatment success. Yucel et al. (8) determined preoperative reflux grade $(O R=0.46, p<0.001)$, amount of injected material $(\mathrm{OR}=0.3, \mathrm{p}=0.046)$, and post-operative orifice morphology $(\mathrm{OR}=11.5, \quad \mathrm{p}=0.001)$ as the most important factors influencing surgical success. The injection technique used, on the other hand, was reported as not being influential in surgical success. We could not show the effect of volume for injected material on surgical success $(1.30 \mathrm{ml}$ vs. $1.23 \mathrm{ml})$. Kessler studied patients with reimplantation surgery after primary injection failure and found VD as the primary factor influencing cure rates among factors, such as ureter orifice morphology, in addition to other factors, such as preoperative reflux grade, presence of VD, injected material amount and injection method (19). In order to suggest any effect of orifice morphology on surgical success, investigators must ask several urologists about the pre/postoperative orifice view for exclusion of inter-observational bias. We did not evaluate the ureteral orifice morphology as Kessler and Yucel have reported (19). Ural et al. (11) reported overall resolution rates in children with reflux and accompanying VD as 58\%, 71\%, 26\% and $21 \%$ for reflux grades 1 through 4 , respectively and suggested that high filling pressure might be a cause of reflux in this group of patients. Resolution rates of reflux in the present study was found to be $75 \%, 77.4 \%, 54.5 \%$ and $35.7 \%$, for each grade, respectively.

Stredele at al. (2) reported that $81.5 \%$ of the ureters were without VUR after the first $\mathrm{Dx} / \mathrm{Ha}$ injection at three months postoperatively and, during long-term follow-up at 3 years, 21.5\% of the initially VUR-free ureters relapsed, showing VUR again on the (nuclide) VCUG. Forty-one of 62 patients were without any complication since the Dx/ $\mathrm{Ha}$ injection. Ten of the remaining 21 patients developed less than 2 , while 11 patients developed more than 2 times non-febrile UTI. None of them developed febrile UTI. In our report, out of 82 patients, 13 (15.8\%) who were compliant with UTI (febrile or afebrile) underwent VCUG. Seven of 13 patients had VUR (8\%). We included also patients with grade 1 VUR in our study unlike Stredele's report (2). Despite exclusion of patients having grade 1 reflux in our study, only 15 patients (11.8\%) developed relapse VUR. However, our study report covered only clinical follow-up results and shorter follow-up time (16 months vs. 24 months) when compared with the previously described 
study. There was still a risk of VUR recurrence in successfully treated children after 3 years of follow-up.

The present study is consistent with the previously published literature, except one setting; it included only patients with OAB. No serious averse events were confronted in the present study. In a sub-group analysis, the success rates got slightly higher up to $61.9 \%$ (44/71) as the patients with known neurogenic bladder and other VD were excluded.

There are several limitations in our study. As this is a retrospective study evaluating the short-term findings in a limited number of patient operated by more than one surgeon, it might have inherent biases and false success rates, and might be underpowered to compare factors known to impact the natural history of VUR resolution in a long-term period. A prospective-randomized study with a larger number of patients should be pursued to overcome these limitations.

\section{Conclusion}

Short-term evaluation of OAB-VUR complex patients showed similar success rates for both forms of endoscopic anti-reflux surgery techniques, namely for STING and double-HIT. Grade of reflux and presence of $\mathrm{VD}$ appears to be the most important factors affecting the success rates in endoscopic anti-reflux surgery in OAB-VUR complex patients.

\section{Ethical Standards}

All patients' parents gave their informed consent prior to their treatment in our academic center. Details that might disclose the identity of the subjects under the present study are omitted.

Ethics Committee Approval: The study were approved by the Marmara University of Local Ethics Committee (ID: 09.2014.0121), Informed Consent: Consent form was filled out by all participants, Concept: Cem Akbal, Tufan Tarcan, Ferruh Şimşek, Design: Cem Akbal, Tufan Tarcan, Ferruh Şimşek, Data Collection or Processing: Asgar Garayev, Çağrı Akın Şekerci, Muhammed Sulukaya, İlker Tinay, Analysis or Interpretation: Ahmet Şahan, Yı̈ören Tanıdır, Literature Search: Ahmet Şahan, Asgar Garayev, Illker Tinay, Writing: Ahmet Şahan, Cem Akbal, Peer-review: Externally peer-reviewed, Conflict of Interest: No conflict of interest was declared by the authors, Financial Disclosure: The authors declared that this study has received no financial support.

\section{References}

1. Peters CA, Skoog SJ, Arant BS Jr, Copp HL, Elder JS, Hudson RG, Khoury $A E$, Lorenzo AJ, Pohl HG, Shapiro E, Snodgrass WT, Diaz M. Summary of the AUA guideline on management of primary vesicoureteral reflux in children. J Urol 2010;184:1134-1144.

2. Stredele RJ, Dietz HG, Stehr M. Long-term results of endoscopic treatment of vesicoureteral reflux in children: comparison of different bulking agents. J Pediatr Urol 2013;9:71-76.

3. Molitierno JA, Scherz HC, Kirsch AJ. Endoscopic treatment of vesicoureteral reflux using dextranomer hyaluronic acid copolymer. J Pediatr Urol $2008 ; 4: 221-228$
4. Kalisvaart JF, Scherz HC, Cuda S, Kaye JD, Kirsch AJ. Intermediate to long-term follow-up indicates low risk of recurrence after Double HIT endoscopic treatment for primary vesico-ureteral reflux. J Pediatr Urol 2012;8:359-365.

5. Kirsch AJ, Perez-Brayfield $M$, Smith EA, Scherz HC. The modified sting procedure to correct vesicoureteral reflux: improved results with submucosal implantation within the intramural ureter. J urol 2004;171:2413-2416.

6. Läckgren G, Kirsch AJ. Surgery Illustrated-Surgical Atlas: Endoscopic treatment of vesicoureteral. BJU Int 2010;105:1332-1347.


W, Jørgensen TM, Rittig $S$, Walle JV, Yeung CK, Djurhuus JC. The standardization of terminology of lower urinary tract function in children and adolescents: report from the Standardisation Committee of the International Children's Continence Society. J urol 2006;176:314-324.

8. Yucel S, Gupta A, Snodgrass W. Multivariate analysis of factors predicting success with dextranomer/hyaluronic acid injection for vesicoureteral reflux. J urol 2007;177:1505-1509.

9. Watters ST, Sung J, Skoog SJ. Endoscopic treatment for vesicoureteral reflux: How important is technique? J Pediatr Urol 2013;9:1192-1197.

10. Fast $A M$, Nees $S N$, Van Batavia JP, Combs AJ, Glassberg Kl.Outcomes of targeted treatment for vesicoureteral reflux in children with nonneurogenic lower urinary tract dysfunction. J urol 2013;190:1028-1033.

11. Ural Z, Ulman I, Avanoglu A. Bladder dynamics and vesicoureteral reflux: factors associated with idiopathic lower urinary tract dysfunction in children. J urol 2008;179:1564-1567.

12. Akbal C, Genc Y, Burgu B, Ozden E, Tekgul S. Dysfunctional voiding and incontinence scoring system: quantitative evaluation of incontinence symptoms in pediatric population. J urol 2005;173:969-973.

13. Lebowitz RL, Olbing $H$, Parkkulainen KV, Smellie JM, Tamminen-Möbius TE. International system of radiographic grading of vesicoureteric reflux. Pediatr radiol 1985;15:105-109.

14. Kirsch AJ, Perez-Brayfield MR, Scherz HC. Minimally invasive treatment of vesicoureteral reflux with endoscopic injection of dextranomer/ hyaluronic acid copolymer: the Children's Hospitals of Atlanta experience. J urol 2003;170:211-215.

15. Altug U, Cakan M, Yilmaz $S$, Yalçinkaya F. Are there predictive factors for the outcome of endoscopic treatment of grade III-V vesicoureteral reflux with dextranomer/hyaluronic acid in children? Pediatr Surg Int 2007;23:585-589.

16. Routh JC, Reinberg Y, Ashley RA, Inman BA, Wolpert JJ, Vandersteen DR, Husmann DA, Kramer SA. Multivariate comparison of the efficacy of intraureteral versus subtrigonal techniques of dextranomer/hyaluronic acid injection. J Urol 2007;178:1702-1705.

17. Méndez R, Somoza I, Tellado MG, Liras J, Sánchez A, Pais E, Vela D. Predictive value of clinical factors for successful endoscopic correction of vesicoureteral reflux grades III-IV. J Pediatr Urol 2006;2:545-550.

18. Lavelle MT, Conlin MJ, Skoog SJ. Subureteral injection of Deflux for correction of reflux: analysis of factors predicting success. Urology 2005;65:564-567.

19. Higham-Kessler J, Reinert SE, Snodgrass WT, Hensle TW, Koyle MA, Hurwitz RS, Cendron M, Diamond DA, Caldamone AA. A review of failures of endoscopic treatment of vesicoureteral reflux with dextranomer microspheres. J urol 2007;177:710-715. 